Zeszyty Naukowe Szkoły Głównej Gospodarstwa Wiejskiego w Warszawie

Problemy Rolnictwa Światowego tom 20 (XXXV), zeszyt 1, 2020: 67-77

DOI: $10.22630 / P R S .2020 .20 .1 .6$

Anna Twardowska ${ }^{1}$

Szkoła Główna Gospodarstwa Wiejskiego w Warszawie

\title{
Wyrównywanie się cen gruntów rolnych w krajach Unii Europejskiej
}

\section{Equalization of Agricultural Land Prices in the European Union Countries}

\begin{abstract}
Synopsis. W artykule poruszono problematykę związaną z kształtowaniem się cen ziemi rolniczej w krajach Unii Europejskiej. Poddano weryfikacji hipotezę dotyczącą występowania beta-konwergencji absolutnej cen ziemi rolnej wśród 20 wybranych państw UE. Badania przeprowadzono dla lat $2006-$ 2017 z wykorzystaniem modeli absolutnej konwergencji typu beta opartych na danych przestrzennych. Uzyskane wyniki badań potwierdzają występowanie tzw. efektu doganiania na rynku cen ziemi rolnej w Unii Europejskiej. Tym samym w krajach, w których początkowo stwierdzono niższy poziom cen ziemi rolnej następuje szybszy wzrost cen, niż w krajach o początkowo wyższym ich poziomie.
\end{abstract}

Slowa kluczowe: beta-konwergencja, ceny ziemi rolnej, Unia Europejska

\begin{abstract}
The paper deals with issues related to the development of agricultural land prices in the countries of the European Union. The hypothesis regarding absolute beta-convergence of agricultural land prices among 20 selected EU countries was verified. The research was carried out for the years 2006 - 2017 using absolute beta convergence models based on spatial data. Obtained test results confirm the occurrence of so-called the effect of catching up on the agricultural land market in the European Union. Thus, in countries where initially a lower level of agricultural land prices were found, there is a faster increase in prices than in countries with initially higher levels.
\end{abstract}

Keywords: beta-convergence, agricultural land prices, European Union

JEL Classification: C19, Q15, R10

\section{Wstęp}

Charakterystycznym zjawiskiem jakie obserwujemy we współczesnym świecie jest postępujący proces integracji gospodarczej. Procesy integracji przyczyniają się do skuteczniejszej alokacji kapitału, bardziej efektywnych inwestycji, transferu wiedzy i technologii, wzrostu konkurencji - co prowadzi do obniżenia kosztów i zwiększenia różnorodności towarów dostępnych dla konsumentów czy poprawy perspektyw wzrostu gospodarczego i zatrudnienia (Milleville, 2009). Oczekiwanym efektem końcowym integracji gospodarczej jest wzrost produkcji oraz dobrobytu społeczeństwa. Podstawą integracji gospodarczej jest przede wszystkim integracja rynkowa, którą charakteryzują konkurencyjne i otwarte rynki, swoboda transferów oraz działanie mechanizmów rynkowych. Integracja rynków przejawia się w różnych formach - strefie wolnego handlu,

${ }^{1}$ mgr inż., Katedra Ekonomii Międzynarodowej i Agrobiznesu SGGW w Warszawie, ul. Nowoursynowska 166, 02-787 Warszawa, e-mail: anna_twardowska@ sggw.edu.pl; https://orcid.org/0000-0002-6079-3044 
unii celnej, unii walutowej, czy unii politycznej. Jedną z form integracji, odzwierciedlającą system przyjęty w Unii Europejskiej, jest wspólny rynek, rozumiany jako swoboda przepływu towarów, usług, osób i czynników produkcji - pracy i kapitału.

Jednym ze sposobów badania stopnia i zmian integracji gospodarczej jest badanie rynków poszczególnych towarów czy usług. Unifikacja rynku towarów rolnych w Unii Europejskiej, została potwierdzona w wielu publikacjach (m. in. Hamulczuk, 2018; Urban i Mroczek, 2011). Prace te dowodziły, że rynki towarów rolnych w Unii Europejskiej podlegają procesom przestrzennej integracji. Analiza zmian na rynku towarów rolnych, prowadzi do kolejnego zagadnienia dotyczącego zmian na rynku czynników produkcji. Obok kapitału i pracy, jednym z podstawowych czynników produkcji jest ziemia. Ze względu na specyficzne cechy ziemi (niemobilność), nie jest możliwy jej transfer z regionów nadwyżkowych do regionów, w których jest odczuwany niedobór tego czynnika. Powstaje zatem pytanie, czy sytuacja na rynku mobilnych towarów rolnych znajduje odzwierciedlenie na niemobilnym rynku ziemi, a także, czy ceny ziemi jako czynnika produkcji, w poszczególnych regionach są ze sobą powiązane. Dotychczasowe badania nad wyrównywaniem się cen ziemi rolniczej potwierdzały, iż pomiędzy państwami tzw. „,starej Unii” a państwami, które uznawane są za „nowych” członków UE zachodzi zmniejszanie się zróżnicowania cen ziemi rolniczej $\mathrm{w}$ czasie, znane jako sigma konwergencja. Występujące zjawisko związane jest $\mathrm{z}$ dynamicznym wzrostem cen ziemi nowych państw członkowskich oraz ze stabilnym poziomem cen ziemi w państwach tzw. starej Unii. Dynamiczny wzrost cen w nowych państwach UE oraz względna stabilizacja na rynkach państw tzw. starej UE prowadzą do stopniowego zmniejszania zróżnicowania poziomu cen ziemi rolniczej w Unii Europejskiej (Twardowska, 2019). Mimo braku mobilności ziemi jako czynnika produkcji, obserwuje się wyrównywanie jego cen, co jest powiązane z praktycznie nieograniczonym przepływem towarów rolno-żywnościowych oraz $\mathrm{z}$ przepływem kapitału.

Celem niniejszego opracowania jest próba wskazania teoretycznych przesłanek wyrównywania się cen ziemi rolniczej oraz określenie występowania tzw. absolutnej konwergencji typu beta cen ziemi w krajach UE. Badania przeprowadzono na podstawie informacji cenowych w latach 2006-2017.

\section{Teoretyczne przesłanki wyrównywania cen ziemi między krajami}

Podstawą do postawienia twierdzenia dotyczącego wzajemnych powiązań cen ziemi jest, wskazywana w literaturze, przestrzenna integracja na rynku towarów rolnych. Dotychczasowe badania integracji rynków rolno-spożywczych i dóbr konsumpcyjnych wykazują stopniowe ujednolicanie się rynków, między innymi także poprzez zmniejszanie się zróżnicowania cen towarów rolnych na rynku europejskim. Zgodnie z literaturą przedmiotu, przyjęto, że integracja na rynku towarów prowadzi w konsekwencji do integracji na rynku czynników produkcji (Krugman i Obstfeld 2007). W prezentowanej analizie skupiono się na zbadaniu rynku ziemi jako jednego z trzech czynników produkcji.

Podejmowane dotychczas badania empiryczne dotyczące wyrównywania się cen czynników produkcji sprowadzały się przede wszystkim do analizy takich czynników produkcji jak praca i kapitał (m. in. Kangasharju, Kerkelä i Pekkala, 2003; Bernard i in. 2002). Badania rynku ziemi w kontekście teorii wyrównywania się cen czynników 
produkcji, przemawiały za potwierdzeniem zmniejszania się zróżnicowania cen ziemi pomiędzy badanymi regionami (m. in. Alston i Johnson 1988).

Teoretyczne wyjaśnienie wyrównywania się cen czynników produkcji znajduje swoje podłoże w teoremacie Heckeshera-Ohlina. Jest to teoria wskazująca, iż zróżnicowanie państw w wyposażeniu $\mathrm{W}$ zasoby stanowi główną siłę napędową handlu międzynarodowego. Teoria Heckeshera-Ohlina jest również nazywana teorią względnej obfitości czynników produkcji, z uwagi na to, iż jej główne założenia koncentrują się na zależności pomiędzy wyposażeniem krajów w czynniki produkcji a ich względnym zużyciem w produkcji dóbr. Rozważania nad teorią Heckeshera-Ohlina prowadził także Paul Samuelson, który rozwinął pojęcie wyrównywania się cen czynników produkcji (Factor Price Equalization - FPE) (Samuelson, 1948).

Teoria Heckeshera-Ohlina opiera się na przykładzie modelu dwuczynnikowego (Rassekh i Thompson 1993). Do wyjaśnienia mechanizmu wyrównywania się względnych cen czynników produkcji przyjęto następujące założenia: dwa kraje (kraj A $i$ kraj B), dwa dobra i dwa czynniki produkcji (praca i ziemia). W prezentowanym modelu przyjmuje się, że produkcja jednego dobra jest ,pracochłonna”, a produkcja drugiego dobra jest „ziemiochłonna”. Cena danego dobra będzie zależała od rodzaju i ilości użytego do jego produkcji czynnika. Należy zatem zadać pytanie o wpływ ceny omawianego czynnika produkcji, jakim jest ziemia, na ceny dóbr. W przypadku dobra $A$ (zaliczonego do kategorii dóbr ,pracochłonnych”, o względnie niedużym zapotrzebowaniu na ziemię podczas produkcji) zmiana ceny ziemi nie będzie wywierała znaczącego wpływu na cenę tego dobra. Natomiast w odniesieniu do dobra B (zgodnie z przyjętymi założeniami określonym jako dobro „ziemiochłonne”, wymagające do produkcji znacznego zasobu ziemi) spadek bądź wzrost cen ziemi znajdzie odzwierciedlenie w cenach tego dobra. Zgodnie z teorią Heckeschera-Ohlina mobilność towarów w handlu międzynarodowym może służyć jako częściowy substytut mobilności czynników, co z kolei może prowadzić do częściowego wyrównania względnych (i bezwzględnych) cen czynników produkcji (Samuelson, 1948). Handel pomiędzy dwoma krajami może stanowić nie tylko wymianę dóbr - oba kraje w sposób pośredni handlują ze sobą również czynnikami produkcji. Kraj A, który produkuje dobro „pracochłonne” nie sprzedaje bezpośrednio czynnika produkcji jakim jest „praca”. Kraj handlując dobrami, dla których produkcji potrzeba relatywnie więcej nakładu pracy niż ziemi, w eksporcie tego dobra uprzedmiatawia więcej „,pracy” niż w jego imporcie. Kraj $\mathrm{B}$, który sprzedaje dobra wymagające w procesie produkcji relatywnie więcej nakładu ziemi niż pracy, pośrednio eksportuje swoją ziemię (Krugman i Obstfeld 2007).

W związku z powyższym, oczekuje się, że na podstawie przestrzennej integracji, jaka występuje na rynkach towarów rolnych, będzie miała również miejsce przestrzenna integracja na rynku czynników produkcji, w prezentowanym przypadku - na rynku ziemi rolniczej.

\section{Dane i metody badań}

Aby zweryfikować występowanie efektu „doganiania” na rynku ziemi rolniczej pomiędzy poszczególnymi państwami Unii Europejskiej, poddano analizie poziom i zmiany cen ziemi rolnej w wybranych dwudziestu państwach Unii Europejskiej (rys. 1). Wybrano kraje, dla których możliwe było uzyskanie wiarygodnych danych dotyczących poziomu cen gruntów rolnych. Analizę przeprowadzono dla danych z lat $2006-2017$. 
Informacje na temat średnich cen gruntów pozyskano $\mathrm{z}$ danych publikowanych przez Eurostat oraz z publikacji Instytutu Ekonomiki Rolnictwa i Gospodarki Żywnościowej Państwowego Instytutu Badawczego, opublikowanych w czasopismach „Rynek ziemi rolniczej. Stan i perspektywy”. Powyższe dane pochodzą z państwowych urzędów statystycznych, ministerstw rolnictwa, ośrodków naukowo-badawczych, oraz innych instytucji i organizacji rolnych zajmujących się gruntami rolnymi w poszczególnych krajach. Dla ujednolicenia opisywanych danych, wszystkie wartości zostały podane w jednej walucie (euro/ha)

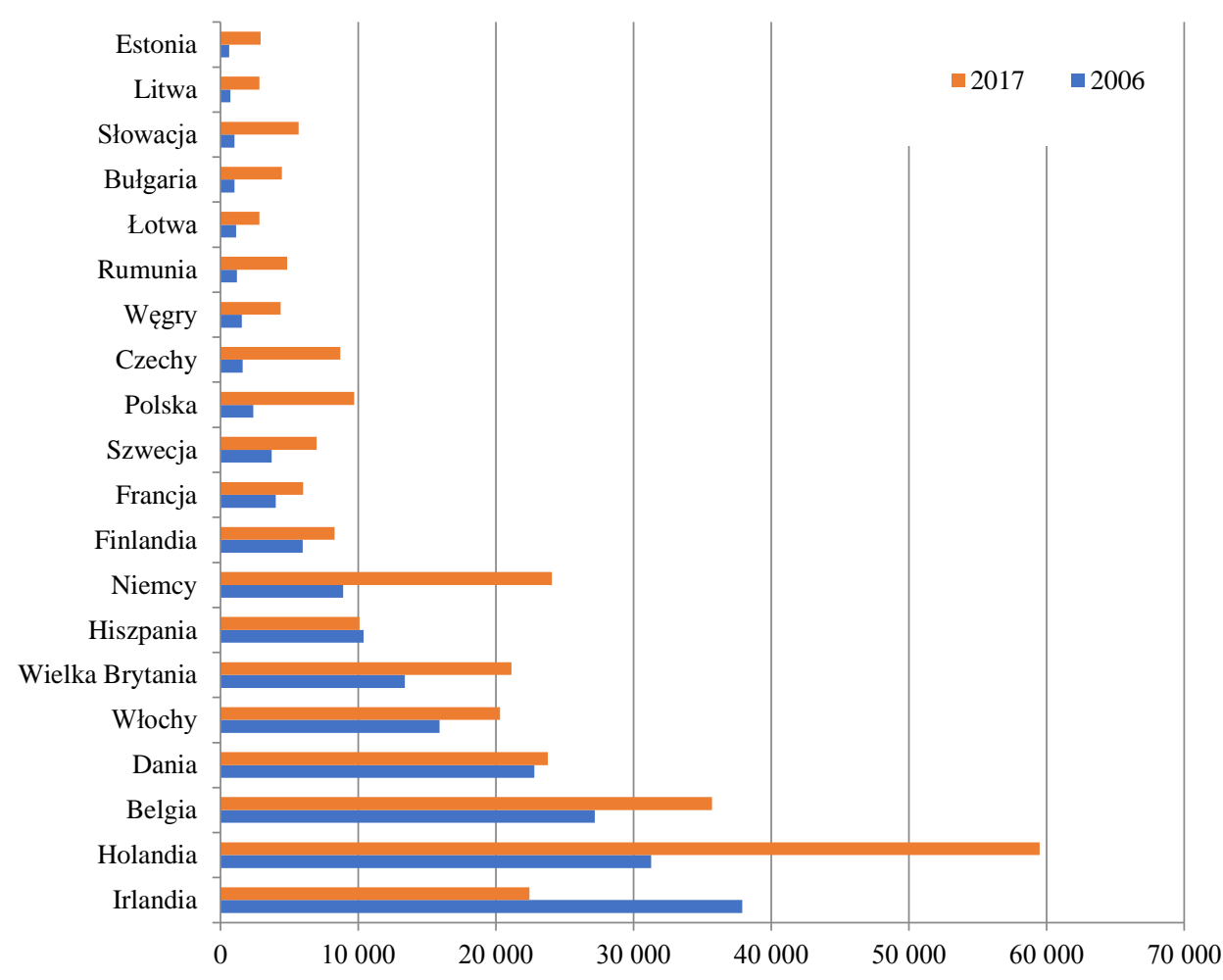

Rys. 1. Ceny gruntów rolnych w latach 2006 i 2017 w wybranych państwach Unii Europejskiej [euro/ha]

Fig. 1. Agricultural land prices in 2006 and 2017 in selected EU Member States [euro/ha]

Źródło: opracowanie własne na podstawie danych IERiGŻ-PIB.

W celu zbadania integracji rynków ziemi w państwach Unii Europejskiej, sprawdzono występowanie zjawiska tzw. konwergencji cen typu beta. Konwergencja typu beta jest zaliczana do tzw. konwergencji klasycznych. Pierwsze koncepcje konwergencji narodziły się w latach osiemdziesiątych XX wieku. Wywodzą się z neoklasycznej teorii wzrostu gospodarczego i stanowią implikację koncepcji o malejącej krańcowej produkcyjności kapitału per capita oraz o egzogenicznym podłożu postępu technologicznego (Nowak 2006). Początkowe badania nad konwergencją gospodarczą (m.in. Baumol 1986, de Long 
1988) skupiały się na badaniu występowania zjawiska konwergencji absolutnej typu beta. Następnie pojawiły się rozważania nad beta-konwergencją warunkową (m. in. Barro i Sala Martin 1992), a ówczesne prace pozwoliły na sformułowanie kolejnego typu konwergencji - nazywanej konwergencją typu sigma.

Koncepcja konwergencji typu beta zakłada występowanie tzw. zjawiska „doganiania”. Zgodnie $\mathrm{z}$ najczęściej przytaczaną definicją, konwergencja typu beta oznacza proces osiągania spójności (zbieżności), gdy regiony słabiej rozwinięte, rozwijają się szybciej niż regiony lepiej rozwinięte (Próchniak i Rapacki 2007) lub, że regiony o niższym poziomie rozwoju charakteryzują się szybszym tempem wzrostu niż kraje bogatsze, co wraz z upływem czasu prowadzi do wyrównywania poziomów dochodów per capita (Berbeka, 2006). W badaniu konwergencji cen, w omawianym przypadku cen ziemi rolniczej, konwergencję typu beta zdefiniowano jako relatywnie szybszy wzrost cen w regionach o początkowo niższym poziomie cen ziemi rolnej niż w regionach, w których ceny na początkowym etapie były wyższe. Konwergencja absolutna występuje wówczas, gdy regiony o niższej wartości zmiennej w okresie początkowym rozwijają się szybciej niż regiony o wyższej wartości zmiennej, niezależnie od ich charakterystyk strukturalnych. Z kolei konwergencja warunkowa ma miejsce, gdy negatywna zależność między przeciętnym tempem wzrostu, a początkowym poziomem wartości zmiennej zachodzi wyłącznie w grupach regionów podobnych do siebie pod względem charakterystyk strukturalnych (Herbst i Wójcik 2012, s. 176). Występowanie $\beta$-konwergencji jest czynnikiem koniecznym, ale niewystarczającym do osiągnięcia innego rodzaju konwergencji - typu sigma (Bal-Domańska 2009). Procesy odwrotne - gdy regiony o początkowo niższych wartościach badanej zmiennej charakteryzują się jej niższą stopą zwrotu oraz gdy zwiększa się dyspersja badanej cechy w czasie - nazywane są beta-dywergencją (Kusideł 2013, s. 45)

Konwergencję absolutną typu beta obliczono według wzoru (Próchniak 2006):

gdzie: $t$-liczba okresów,

$$
\frac{1}{t}\left(\ln y_{t}-\ln y_{0}\right)=\alpha_{0}+\alpha_{1} \ln y_{0}
$$

$y_{t}$ - wartość zmiennej w okresie początkowym,

$y_{0}$ - wartość zmiennej w okresie końcowym.

Konwergencja typu beta występuje wówczas, gdy oszacowany parametr $\alpha_{1}$ jest ujemny i statystycznie istotny. Na jego podstawie obliczamy współczynnik $\beta$ określający tempo zbieżności do hipotetycznego stanu równowagi długookresowej (Próchniak $2006 \mathrm{~s}$. 75):

$$
\beta=-\frac{1}{t} \ln \left(1+\alpha_{1} t\right)
$$

Na podstawie wyników konwergencji beta, określa się tzw. współczynnik zbieżności half-life. Współczynnik zbieżności wskazuje czas potrzebny do redukcji połowy odległości do wspólnego poziomu cen (Dzik-Walczak 2014). Współczynnik zbieżności half-life oblicza się za pomocą następującego wzoru (Kusideł 2013, s. 49):

$$
h l=\frac{\ln 2}{\beta} .
$$

\section{Wyniki badań}

Rynek ziemi rolniczej w Unii Europejskiej jest zróżnicowany pomiędzy poszczególnymi państwami. Jest to wynikiem wielu czynników, do których można zaliczyć 
czynniki ekonomiczne, takie jak sytuacja gospodarcza kraju, poziom cen czy inflacji oraz czynniki geograficzne, związane z podażą ziemi rolnej. Takie państwa jak Holandia czy Belgia charakteryzują się bardzo niewielkimi zasobami ziemi, która może być wykorzystywana na cele rolnicze, zatem przy małej podaży tych terenów, ich cena jest wysoka. Coraz wyraźniejszy staje się także znaczny wzrost cen ziemi rolnej położonej wokół dużych metropolii. Ich wartość stale wzrasta $\mathrm{z}$ uwagi na możliwe w przyszłości zagospodarowanie w inny niż rolniczy sposób - na przykład na cele mieszkaniowe. Do innych czynników, które mogą wpływać na rynek rolniczy, w tym także na rynek ziemi rolniczej, możemy zaliczyć kulturę rolną, rodzaj gleb, poziom technologii w rolnictwie czy wielkość gospodarstw rolnych.

W Europie najwyższe jednostkowe ceny ziemi rolniczej, po przeliczeniu na wspólną walutę, mają miejsce w krajach Europy Zachodniej (rys. 1). Na tle innych państw, najwyższe ceny odnotowuje się w Holandii, Belgii, Danii, w Niemczech czy Wielkiej Brytanii. Najniższe ceny dotyczą państw leżących na wschodzie Europy, występują między innymi na Litwie, Łotwie, w Estonii i Bułgarii.

W analizowanym okresie (tzn. w latach 2006 - 2017) wzrost cen ziemi rolniczej nastąpił we wszystkich $\mathrm{z}$ opisywanych państw (za wyjątkiem Irlandii). Największy procentowy wzrost cen miał miejsce $\mathrm{w}$ takich państwach jak: Estonia (wzrost pięciokrotny), Węgry, Słowacja, Rumunia, Czechy, Litwa czy Bułgaria (ponad czterokrotny wzrost cen jednostkowych). Najmniejszy procentowy wzrost cen odnotowany między innymi na Łotwie, we Francji, Danii i we Włoszech (wzrost cen w roku 2017 w odniesieniu do roku 2006 na poziomie 25-30\%) oraz w większości państw zaliczanych do krajów tzw. „starej” Unii Europejskiej. Jako główne czynniki wpływające na dynamiczny, skokowy wzrost renty z tytułu posiadania ziemi rolniczej w krajach przyjętych do UE po 2004 roku, wskazywane są czynniki pozarolnicze, związane z gospodarką gruntami w ramach polityki europejskiej. Możliwość pozyskania dofinansowania przez rolników oraz wsparcie bezpośrednie $\mathrm{w}$ formie dopłat do gruntów rolnych znacząco zwiększyło zainteresowanie gruntami rolnymi, co bezpośrednio przełożyło się na wzrost ich cen (Kurowska, Ogryzek i Kryszk 2016).

Ze względu na poziom oraz zmiany średnich cen gruntów rolnych w poszczególnych państwach Unii Europejskiej, rynek gruntów można podzielić na dwie grupy (Twardowska 2019):

- rynek gruntów rolnych w tzw. „starych” państwach Unii Europejskiej. W większości z tych państw średnie ceny gruntów rolnych od lat utrzymują się na równomiernym, wysokim poziomie, przeważają transakcje wolnorynkowe. Na zmiany cen ziemi wpływ ma przede wszystkim sytuacja gospodarcza danego kraju oraz popyt na grunty w celach lokacyjnych. W grupie tzw. „starych” członków Unii znalazły się: Belgia, Dania, Finlandia, Francja, Hiszpania, Holandia, Irlandia, Niemcy, Szwecja, Włochy i Wielka Brytania

- rynek gruntów rolnych w tzw. „nowych” państwach Unii Europejskiej - sytuacja na tych rynkach jest dynamiczna i zależy od specyfiki danego kraju, w większości państw odnotowano znaczny wzrost cen gruntów rolnych oraz ożywienie na rynku po przystąpieniu do UE. Do „nowych” państw Unii Europejskiej zaliczono Bułgarię, Czechy Estonię, Litwę, Łotwę, Rumunię, Słowację, Węgry oraz Polskę. 
Średnie ceny ziemi rolniczej we wskazanych powyżej dwóch grupach znacząco różnią się między sobą - ceny ziemi w państwach tzw. „starej Unii” są kilkukrotnie wyższe niż ceny ziemi w grupie tzw. „,nowych państw” UE (rys. 2).

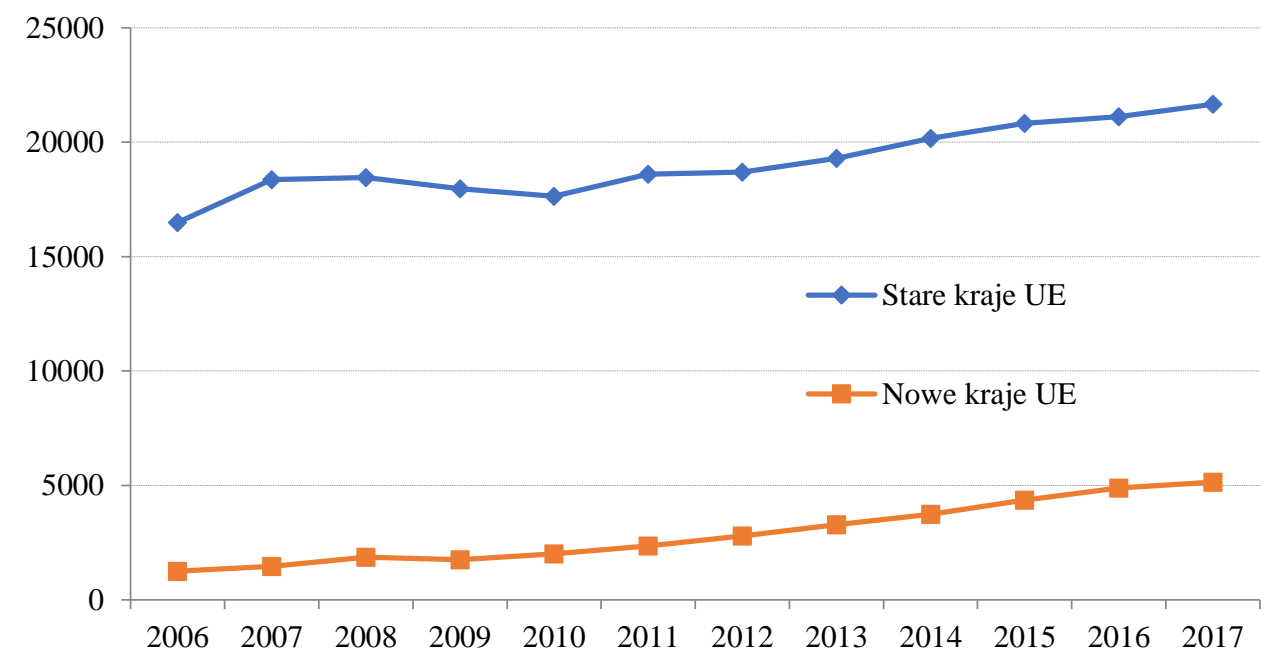

Rys. 2. Średnie ceny gruntów rolnych w grupie "starych" państw UE oraz w grupie "nowych" państw UE w latach 2006-2017 (euro/ha)

Fig. 2. Average agricultural land prices in OMS and NMS UE in 2006-2017 (euro/ha)

Źródło: opracowanie własne.

Dla potrzeb określenia integracji rynków ziemi rolnej w Unii Europejskiej, zweryfikowano występowanie zjawiska beta konwergencji w latach 2006 - 2017. Wynik przeprowadzonej analizy przedstawia rys. 3. Na osi pionowej oznaczono średnie zmiany logarytmów cen w latach 2006-2017 (po pomnożeniu przez 100 daje to średnią roczną procentową zmianę cen), natomiast oś pozioma wskazuje poziom cen ziemi w okresie początkowym - logarytm naturalny zmiennej). Im nachylenie linii trendu jest bardziej strome, tym procesy konwergencji są silniejsze.

W wyniku przeprowadzonego badania stwierdzono, że w badanym okresie ceny na rynku gruntów rolnych w Unii Europejskiej rozwijały się zgodnie z hipotezą konwergencji typu $\beta$. Regiony, które na początku analizowanego okresu charakteryzowały się niższym poziomem cen $w$ następnych analizowanych latach osiągnęły przeciętnie szybsze tempo wzrostu cen gruntów rolnych niż regiony z wyższym poziomem cen w roku 2006. Nachylenie linii regresji było ujemne, a parametr $\alpha_{1}$ przyjął wartość ujemną. Obliczony współczynnik $\beta$ wynosi 0,0414 , co oznacza, że roczne tempo zbliżania się poziomu cen gruntów w analizowanym okresie do stanu równowagi długookresowej wynosi $4,14 \%$. Zależność jest istotna statystycznie ( $p$-value <0,05). Współczynnik zbieżności (half-life), określający czas potrzebny do redukcji połowy odległości do wspólnego poziomu cen wynosi 16,4 lat.

Na rysunku 3 można wyodrębnić dwa skupiska obrazujące zbliżone zmienne - grupę tzw. „nowych” i „starych” państw UE. Do grupy tzw. „,nowych państw” zaliczono dziewięć wybranych państw Unii. Ich położenie na wykresie wskazuje na wyższe roczne zmiany cen 
oraz początkowy niższy poziom cen. W grupie tzw. „starych państw” Unii znalazło się jedenaście wybranych państw - grupa tych państw charakteryzuje się wyższym początkowym poziomem cen oraz niższymi zmianami w ujęciu rocznym.

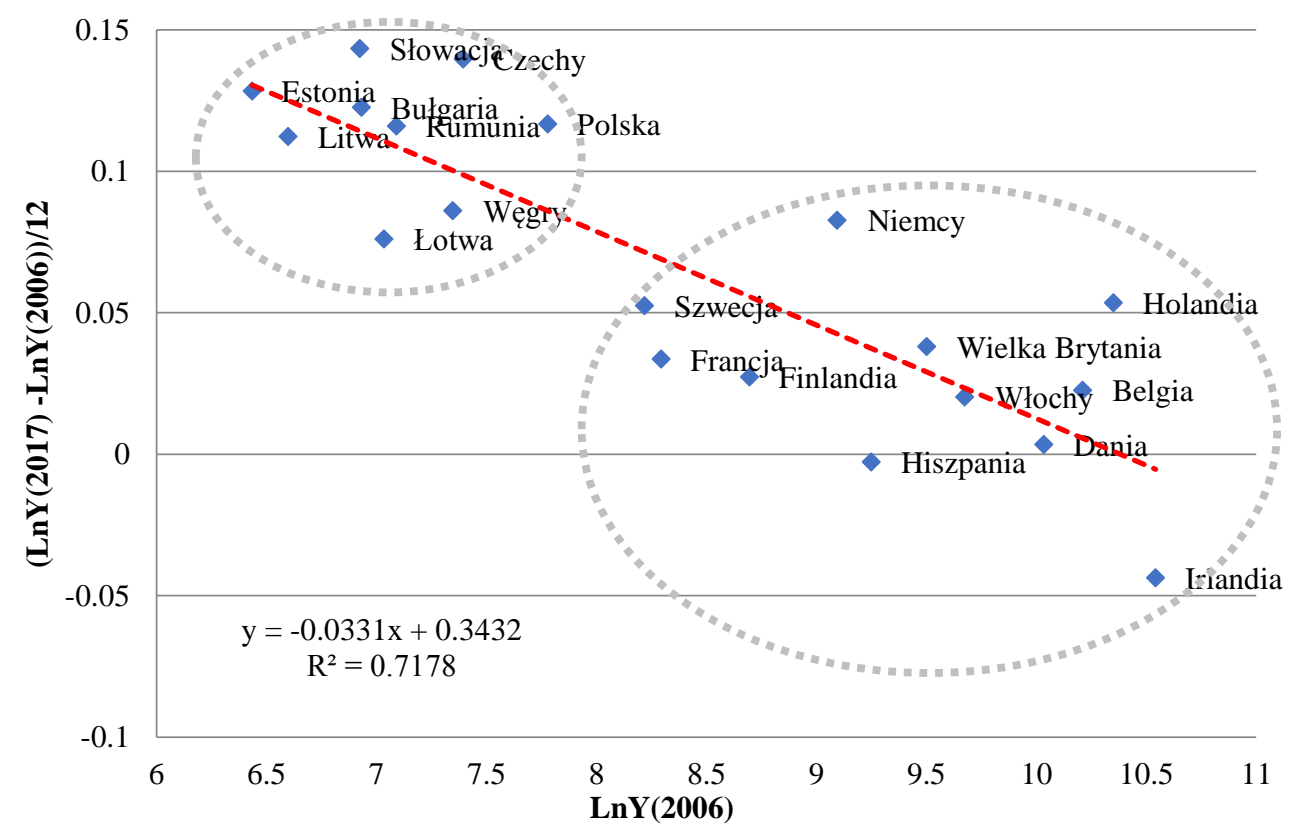

Rys. 3. Konwergencja typu beta pomiędzy cenami gruntów rolnych w państwach UE

Fig. 3. Beta convergence of agricultural land prices in European Union countries

Źródło: opracowanie własne na podstawie wyników badań.

Dynamiczny wzrost średnich cen ziemi w nowych państwach członkowskich (w szczególności na Słowacji, w Czechach, Bułgarii czy w Polsce) oraz względnie stabilny poziom cen ziemi w państwach tzw. starej Unii (przede wszystkim w Belgii, Danii, Francji, we Włoszech) przyczyniły się do stopniowego zmniejszania się zróżnicowania cen ziemi pomiędzy grupą tzw. „nowych” i „starych” państw Unii. Różnica w wysokości cen jest wciąż znacząca, jednak dane wskazują, iż występujące jednocześnie dwa zjawiska stabilizacja i przewidywalność rynków tzw. „starych państw” oraz duża zmienność obserwowana na rynkach tzw. „nowych” państw, po ich wstąpieniu do Unii - może w przyszłości prowadzić do stopniowego ujednolicania rynków ziemi rolniczej.

W kolejnym etapie zweryfikowano występowanie „efektu doganiania” w dwóch poszczególnych grupach, wyodrębnionych powyżej - w grupie tzw. „starych państw” UE i „nowych państw” UE. W grupie tzw. „starych państw” linia nachylenia jest ujemna, jednak parametr $\alpha_{1}$ nie wykazuje istotności statystycznej, a zatem nie można potwierdzić występowania konwergencji cen typu beta w tej grupie. Zatem, przeprowadzona analiza nie potwierdza występowania efektu doganiania cen ziemi rolnej w grupie tzw. „starych państw" UE (rys. 4). 


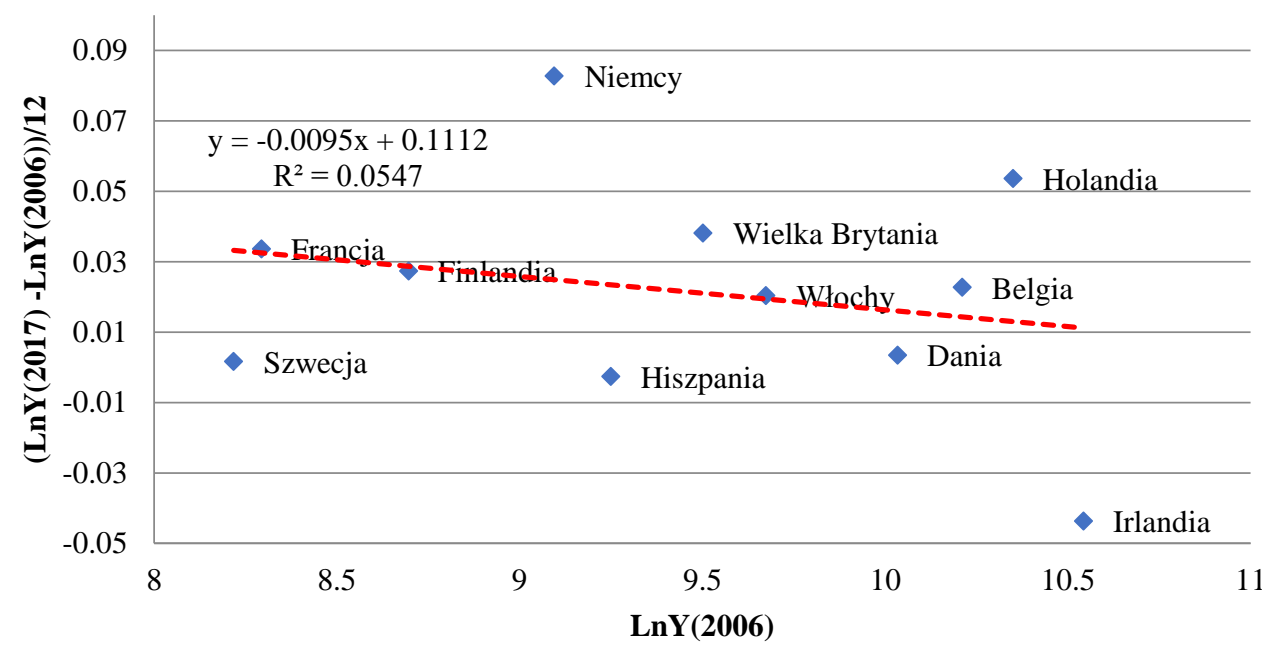

Rys. 4. Konwergencja typu beta pomiędzy cenami gruntów rolnych w tzw. „starych państwach” UE Fig. 4. Beta convergence of agricultural land prices in 'old UE Member States' Źródło: opracowanie własne na podstawie wyników badań.

Sytuacja na rynku gruntów rolnych w grupie tzw. „nowych państw” Unii Europejskiej przedstawia się podobnie. Oszacowana i przedstawiona na rys. 5 linia trendu o nachyleniu ujemnym nie jest statystycznie istotna ( $p$-value > 0,05). W związku z powyższym brak jest przesłanek, które potwierdziłyby zachodzenie procesów konwergencji cen ziemi rolnej wśród tych państw.

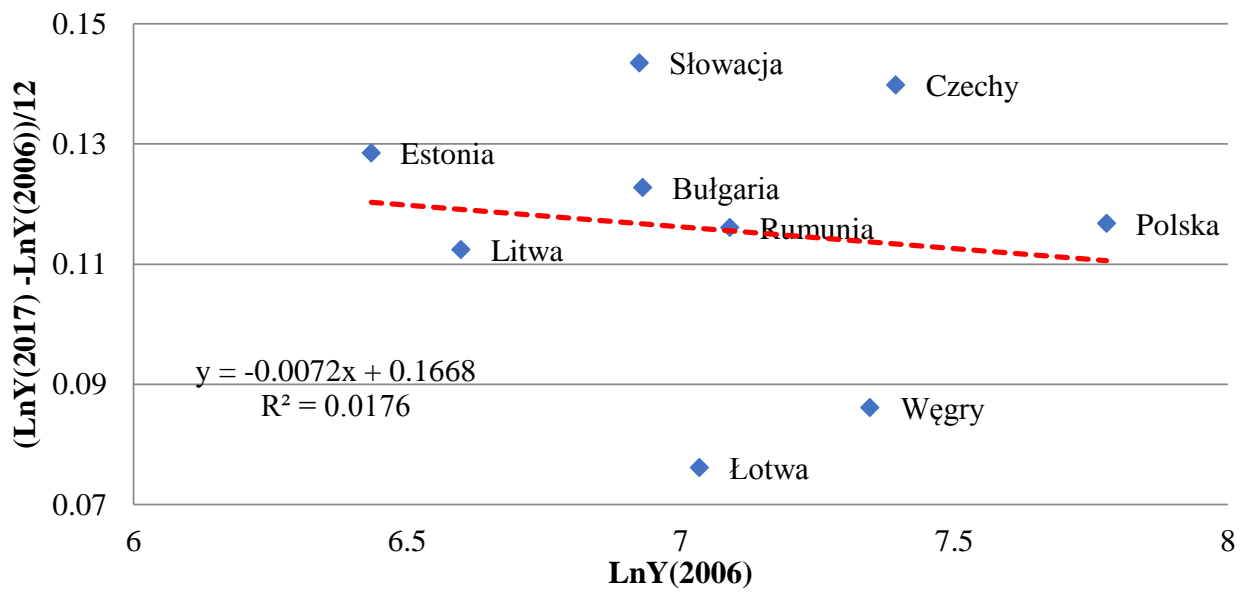

Rys. 5. Konwergencja typu beta pomiędzy cenami gruntów rolnych w tzw. „nowych państwach” UE

Fig. 5. Beta convergence of agricultural land prices in 'new UE Member States'

Źródło: opracowanie własne na podstawie wyników badań. 


\section{A. Twardowska}

Powyższe wyniki wskazują, iż „efekt doganiania” cen występuje pomiędzy nowymi, a starymi państwami Unii Europejskiej - to znaczy, na dynamicznie rozwijających się rynkach nowych państw Unii ceny osiągają szybsze tempo wzrostu, co prowadzi do stopniowego zbliżania się do poziomu cen w państwach starej Unii. Pomimo, iż dystans cenowy, który dzieli obecnie wspomniane grupy jest znaczący, wskazuje na tendencje występujące na rynku ziemi rolnej.

\section{Podsumowanie}

Na rynku ziemi rolnej w państwach Unii Europejskiej występuje duże zróżnicowanie cen pomiędzy grupą tzw. „starych” państw UE, a państwami określanymi jako nowi członkowie Unii. Pomimo dużych dysproporcji cenowych obserwowanych na tym rynku, przeprowadzona analiza potwierdza występowanie absolutnej beta-konwergencji cenowej na rynku ziemi rolniczej w UE. Oznacza to, iż w dynamika zmiany poziomu cen w państwach, które początkowo charakteryzowały się jej niższym poziomem jest większa, niż w krajach o stosunkowo wyższym poziomie cen ziemi rolnej. Występowanie betakonwergencji określane jest mianem „efektu doganiania” i oznacza, iż kraje o niższym średnim poziomie cen niejako doganiają państwa, w których ceny są wyższe. Powyższa analiza sygnalizuje $\mathrm{w}$ jakim kierunku może podążać rynek ziemi rolnej w Unii Europejskiej.

Wyrównywanie się cen ziemi jest pośrednią konsekwencją integracji mobilnych rynków towarów rolnych. Należy jednak pamiętać, że jest wiele czynników wpływających na ceny ziemi rolniczej, a sytuacja na rynkach czynników dóbr jest jedną ze składowych. W odniesieniu do cen ziemi rolniczej w Unii Europejskiej jako czynniki sprzyjające wyrównywaniu cen należy wskazać między innymi politykę rolną $\mathrm{z}$ dopłatami bezpośrednimi, podaż ziemi rolniczej, warunki geograficzne czy poziom technologii w rolnictwie. Kształtowanie się cen na rynku ziemi rolniczej w Europie oraz zmian zachodzących na tym rynku jest zagadnieniem wieloaspektowym wymagającym prowadzenia dalszych badań.

\section{Literatura}

Alston J., Johnson, P. (1988). Factor price equalisation among international farmland markets. Australian Journal of Agricultural Economics, 2(2-3), 142-152.

Bal-Domańska, B. (2009). Ekonometryczna analiza sigma i beta konwergencji regionów Unii Europejskiej (Econometric analysis of sigma and beta Convergence in the European Union Regions). Prace Naukowe Uniwersytetu Ekonomicznego we Wrocławiu, 76, 9-24.

Barro, R.J., Sala-i-Martin, X.X. (1992). Convergence. Journal of Political Economy, 100(2), 223-251.

Baumol, W.J. (1986). Productivity Growth, Convergence, and Welfare. American Economic Review, 76, $1072-1085$

Berbeka, J. (2006). Konwergencja gospodarcza a konwergencja społeczna krajów Unii Europejskiej (15) w latach 1985-2002 (Economic and Social Convergence of EU Countries (15) in years 1985-2002). Nierówności Spoteczne a Wzrost Gospodarczy, 8, 267-280.

Bernard, A., Redding, S., Schott, P., Simpson, H. (2002). Factor Price Equalization in the UK? National Bureau of Economics Research Working, Paper 9052, Cambridge.

De Long, J. B. (1988). Productivity Growth, Convergence, and Welfare: Comment, American Economic Review, $78,1138-1154$. 
Dzik-Walczak, A. (2014). Tempo konwergencji cenowej w krajach Unii Europejskiej (The pace of price convergence in the countries of the European Union). Ekonomia. Rynek, Gospodarka, Spoteczeństwo, 36/2014, 91-123.

Hamulczuk, M. (2018). Przestrzenna integracja towarowych rynków rolnych na przykładzie pszenicy (Spatial integration of commodity agricultural markets on the example of wheat). Wydawnictwo SGGW, Warszawa.

Herbst, M., Wójcik, P. (2012). Wzrost gospodarczy i dywergencja poziomów dochodu w polskich podregionach niektóre determinanty i efekty przestrzenne (Economic growth and divergence of income levels in Polish subregions - some determinants and spatial effects). Ekonomista, 2, 175-201.

Kangasharju, Kerkelä i Pekkala (2003). Factor price Equalization in Finland. Paper presented at the 43rd European Congress of the Regional Science Association (ERSA) in Jyväskylä, Finland.

Krugman, P., Obstfeld, M. (2007). Ekonomia międzynarodowa. Teoria i polityka. t. 1 (International economics. Theory and Policy). Wydawnictwo PWN, Warszawa.

Kurowska, K., Ogryzek, M., Kryszk, H. (2016). Kształtowanie się cen nieruchomości rolnych po wstapieniu Polski do Unii Europejskiej na przykładzie Agencji Nieruchomości Rolnych OT Olsztyn. (Development of agricultural real estate prices after Poland's accession to the European Union on the example of the Olsztyn branch of APA). Studia Obszarów Wiejskich, 42, 75-86.

Kusideł, E. (2013). Konwergencja gospodarcza w Polsce i jej znaczenie w osiąganiu celów polityki spójności (Economic convergence in Poland and its importance in achieving the objectives of cohesion policy). Wyd. Uniwersytetu Łódzkiego, Łódź.

Milleville, J. (2009). Wpływ integracji ekonomicznej na handel ugrupowania regionalnego na przykładzie Unii Europejskiej (The impact of economic integration on trade in a regional grouping on the example of the European Union). Barometr Regionalny, 2(16), 55-69.

Nowak, W. (2006). Koncepcje konwergencji w teorii wzrostu gospodarczego (Concepts of Convergence in the Growth Theory). Nierówności Spoleczne a Wzrost Gospodarczy, 8, 253-266.

Próchniak, M., Rapacki, R. (2007). Konwergencja beta i sigma w krajach postsocjalistycznych w latach 19902005 (Beta and Sigma Convergence in the Post-Socialist Countries in 1990-2005). Bank i Kredyt, 38(8-9), 42-60.

Próchniak, M. (2006). Realna konwergencja typu beta $(\beta)$ i sigma $(\sigma)$ w świetle badań empirycznych. (Real beta $(\beta)$ and sigma $(\sigma)$ convergence. The review of empirical studies). Zeszyty Naukowe Szkoty Gtównej Handlowej. Kolegium Gospodarki Światowej, 20/2006, 74-91.

Rassekh F., Thompson H. (1993). Factor Price Equalization: Theory and Evidence. Journal of Economic Integration, 8(1), 1-32.

Rynek ziemi rolniczej, stan i perspektywy. Analizy rynkowe. Lata 2010-2018. Wyd. IERiGŻ, Warszawa.

Samuelson, P.A. (1948). International Trade and Equalization of Factor Prices. Economic Journal, 58, 163-184.

Twardowska, A. (2019). Konwergencja typu sigma cen gruntów rolnych w państwach Unii Europejskiej (Sigma convergence of agricultural land prices in European Union countries). Problemy Rolnictwa Swiatowego, 19(1), 133-143. DOI: 10.22630/PRS.2019.19.1.12

Urban, R., Mroczek, R. (2011). Postępy integracji europejskiej w sektorze żywnościowym (Progress of European integration in the food sector). Zagadnienia Ekonomiki Rolnej, 2, 59-77.

Do cytowania / For citation:

Twardowska A. (2020). Wyrównywanie się cen gruntów rolnych w krajach Unii Europejskiej. Problemy Rolnictwa Światowego, 20(1), 67-77; DOI: 10.22630/PRS.2020.20.1.6

Twardowska A. (2020). Equalization of Agricultural Land Prices in the European Union Countries (in Polish). Problems of World Agriculture, 20(1), 67-77; DOI: 10.22630/PRS.2020.20.1.6 